the work of the commissions. The formation of such commissions would be a great step forward in promoting the international recognition of trusteeship, as opposed to ownership, of Colonial territories.

\section{Aspects of Demobilization}

THE jmportant address of Sir William Jowitt to representatives of municipal and business interests of Merseyside, delivered in Liverpool on June 17, directed attention to a vital but complex aspect of post-war reconstruction. The complexity of the problems of demobilization should be apparent to all, but Sir William Jowitt's remarks on the subject were reassuring in that he said that the fatal mistakes of 1918-19 will not be repeated. Sir William urged that it would be foolish to involve members of the Fighting Forces in any controversy about rival schemes of demobilization ; past experience justifies the reminder that it would be highly dangerous. The very difficulty of devising a fair and efficient scheme of demobilizing in the shortest possible time a huge number of men and wcmen and resettling them in peace-time work in industries, most of which would be short of raw materials, while many of the factories would require re-tooling and re-arranging, makes it imperative that a policy should be decided upon promptly and that it should be explained intelligently as soon as possible to prevent misunderstanding later on. Sir William Jowitt stated that the Government has adopted a scheme in which the guiding factors are age and length of service. Clearly, however, demobilization cannot be based entirely on these principles. The necessity for armies of occupation, apart from the probability of the war with Japan continuing after Germany has been defeated, will involve a partial demobilization, and the release of men may have to be determined to some extent on transport grounds, for example. Similar considerations may apply to industry. A more orderly transition from war to peace than in 1918 means that some workers will be more urgently required than others when peace. time industry is starting up and the process of reequipment and reconstruction commences.

The Economist has indicated some broad principles of industrial demobilization that merit consideration. Capacity capable of working directly for export should be freed from war obligations as soon as possible. Food, clothing and shelter should come before luxuries. Industries capable of being reconverted to peace work without expensive re-equipment and re-tooling should be allowed to turn over as soon as practicable, to economize the resources needed for immediate reconstruction. British demobilization, both of machines and men, should be an integrated part, not only of the continuing war effort of the United Nations, but also of the joint plans made by them for relief and reconstruction on a world scale. The service of such principles leaves no room for pointless argument, but equally it demands of the Government prompt decisions which must be made known and fully explained. In demobilization-and indeed in reconstruction generally-the channels of assent can never be dug too deep if acrimony is to be avoided.

\section{Association of Teachers in Technical Institutions}

AT the annual conference of the Association of Teachers in Technical Institutions, held in London during Whitsuntide, Mr. J. C. Hazelip of the Leeds College of Commerce was inducted as president of the Association. It is some fifteen years since a teacher of commerce was elected to the office. In his presidential address Mr. Hazelip referred to the additional work undertaken by technical colleges during the War. It includes training of R.A.F. and Royal Navy personnel in radio work and of the R.A.O.C. and the R.E.M.E. for the many maintenance jobs which a mechanical army needs in the field. There is also the training of members of the A.T.S. for clerical and other work. Mr. Hazelip stressed the importance of this contribution by the technical colleges to the national war effort "since success in modern warfare is largely a matter of being in possession of the necessary equipment and of the technical skill to keep it in working order". Thus, he said, the work of technical education is an important factor in bringing the present struggle to a successful issue. He.stressed. too, the fact that this additional work had gone on "without interference with normal technical college activities". With the possibilities of an Education Bill in mind Mr. Hazelip sketched arguments against merging junior technical and commercial schools into a "multilateral school". Technical education, he said, must be conducted in an atmosphere of realism and must be able to call upon the services of men and women who themselves had experienced the difficulties and problems "inherent in the spheres for which the students are being prepared educationally". Technical education must be dovetailed into the industrial and commercial life of the community round it. This realistic atmosphere, he said, could not be found in the normal secondary school. He insisted, however, that notwithstanding the realism of its approach, the junior technical school in its work in English subjects, science and foreign languages, would stand comparison with any similar work now being carried on in any other type of post-primary school.

\section{War Background Studies}

No. 7 of the series of Smithsonian Institution War Background Studies, by J. F. Embree, is devoted to an account of the Japanese nation, its origins and present social structure. The reader is assumed to have some familiarity with Japanese art and litera. ture, costume and types of building. The economic framework of the lives of the people is only very briefly touched upon, and nothing is said about the physical geography or climatic conditions of the country. On the other hand, nearly half of the 36 pages are devoted to the family and household structure and to the customs surrounding the events of the individual life from birth to death, and there is a short chapter on religious beliefs. The author is of the opinion that the obvious differences between the mental processes of adult Japanese and Americans are solely the result of these customs, outlook, and beliefs. Perhaps the most helpful and charming feature of this brochure is its sixteen excellent photographic plates.

No. '8 of these Smithsonian pamphlets, by H. G. Deignan, gives an account of Siam and its inhabitants. In this case a description of the geographical setting is given, and the whole work might be considered as an introduction, but little more, to what would indeed prove a very interesting study. The region dealt with can be divided into a northern, an eastern and a central area, the latter passing down south. wards into the Malay peninsula to the frontier of the Straits Settlements. The aboriginal Negrito popula. 
tion can to-day only be found in isolated groups in the hills : at least three migrations from the north having at various times overrun the land. It was but a few centuries ago that a number of petty kingdoms arose, and only comparatively recently that what can be called a*real national feeling has developed. Siam is a country little known to the average white man. It merits somewhat more detailed treatment than has been possible in these 18 pages. The illustrations, once again, are delightful.

\section{Work of the Tennessee Valley Authority}

THE article "T.V.A. An Achievement of Democratic Planning", by Dr. Julian Huxley, which occupies the greater part of the June number of The Architectural Review, should be of wide interest in view of the absence in Britain of adequate descriptions of the work of the Tennessee Valley Authority. This concise but comprehensive account of T.V.A. in all its implications, which is illustrated by many photographs, most of them new, gives a striking demonstration of the possibilities of judiciously and democratically applied regional planning. The article is timely, for in the post-war planning which must be undertaken in Great Britain we cannot afford to neglect the experience gained in ten years work on the world's boldest venture in regional reconstruction. Moreover, Dr. Huxley includes a critical examination of the limiting conditions of such democratic planning and stresses the essential characteristics : the making of the greatest number of decisions on the spot; development so far as possible of the active participation of the people themselves; co-ordination in the field of the work of all the other agencies concerned; and decentralization of the idea behind an administration so that its planning becomes a part of public opinion. The provision of full powers for a limited function with the organization developed, and the special methods of survey and system of research deliberately adjusted to consumer needs, are all new tools, as Dr. Huxley points out, which will be of service to any democracy in its struggle to control its own social destiny.

Scientific workers will be particularly interested in Dr. Huxley's concise account of research carried out by the Tennessee Valley Authority. In its chemical laboratories a method has been worked out for extracting aluminium from certain common types of clay, which has reached the pilot plant stage, and work on the extraction of magnesium from olivine is also coming to the pilot stage. In the biological field, valuable research has been carried out on malaria control, the incidence of malaria and the encouragement of fish life. The most important aspect of its agricultural research is concerned with the prevention of erosion, including the growing of new cover-crops, while the investigation devoted to the perfecting of agricultural machinery is an excellent example of research carried out and applied from the point of view of consumer interests. This has led, for example, to an electric hay-drier, costing less than 10 per cent of the previous cheapest drier on the. market, and a cheap furrow seeder. Elaborate experiments have been conducted to discover suitable trees and shrubs which will yield crops of fruit or nuts suitable for direct human consumption or available for pigs or other animal stock. Much research has been put into the development of a new type of pressure-cooker for producing cottonseed meal and oil. Other research has led to the development of quick-freezing machinery suitable for use by farmers' co-operatives, which has much increased the growing of various fruit crops. The planned surveys of the Authority are of equal interest, and a new type of land classification has been worked out with the co-operation of the National Resources Planning Board; and a land-use survey has also been prepared for the most important areas of the Tennessee Valley.

\section{Aid for Chinese University Students}

The International Student Service Committee in Chungking is a constituent member of the National Student Relief Committee, which works in close cooperation with the Chinese Government and enjoys the full support of the United Aid to China Fund in Great Britain. Among other schemes, the National Student Relief Committee has organized a system of national scholarships, under which two hundred select students receive free maintenance, university education and constant tuition. The International Student Service Committee in Chungking has made itself specially responsible for the creation of a student centre at Shapingba, near Chungking, for refugee students from the occupied zones, and from all parts of Free China. A large percentage of them is homeless and penniless; others receive small grants for food, books, clothes and university fees. A wellstocked library is maintained for them; discussion groups are run on many subjects, including economics, diplomacy and current international topics.

The International Student Service in Great Britain (11D, Regent Street, London, S.W.1) has during past years sent out regular appeals in aid of the universities of China. It has been able to send out more than $£ 1,000$ annually, and hopes to be able to continue this assistance. Any amount collected is now being passed on to the United Aid to China Fund, which has promised to transfer the donations and to make racommendations to Madame Chiang Kai Chek, in whose hands lies the allocation of funds in China. Further information concerning its activities in this connexion can be obtained from the Secretary of the Service, at the above address.

\section{Protection from $\mathrm{X}$-rays and Radium}

THE revised edition of the recommendations of the British X.Ray and Radium Protection Committee (32 Welbeck Street, London, W.1) embodies no drastic changes from the previous issue of this report. Certain precautions have been made more precise, and data relating to more powerful $\mathrm{X}$-ray apparatus and larger quantities of radium used as mass units have been included. Thanks to these recommenda. tions, the extension of irradiation methods into industrial practice should not be followed by an increase in the band of X-ray martyrs who suffered during the early years of the introduction of these methods into medicine. Attention is directed in the report to special Defence Regulations relating to the precautions to be observed by all those engaged in painting objects with radioactive fluorescent mixtures. Although reference is made to the desirability of systematic blood-tests and the measurement of the concentration of radon in expired air, it is strange that no recommendation is made for the periodical inspection of the hands of persons habitually engaged in the manipulation of radioactive prepara. tions or containers. Another apparent omission is the 